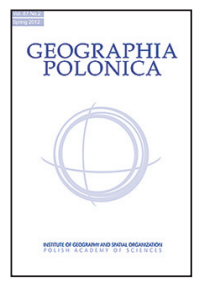

\title{
BIOGEOGRAPHY IN THE EARLY TWENTY-FIRST CENTURY: A SCIENCE WITH INCREASING SIGNIFICANCE FOR EARTH'S CHANGES AND CHALLENGES
}

\section{Udo Schickhoff ${ }^{1,2}$ - Mark A. Blumler ${ }^{3}$ - Andrew C. Millington ${ }^{4}$}

${ }^{1}$ Chair of the IGU Commission on Biogeography and Biodiversity

${ }^{2}$ University of Hamburg

Institute of Geography

CEN Center for Earth System Research and Sustainability

Bundesstr. 55, 20146 Hamburg: Germany

e-mail: schickhoff@geowiss.uni-hamburg.de

${ }^{3}$ Binghamton University

Department of Geography

4400 Vestal Parkway East, Binghamton, 13902 New York: USA

e-mail: mablum@binghamton.edu

${ }^{4}$ Flinders University

School of the Environment

GPO Box 2100, SA 5001 Adelaide: Australia

e-mail: andrew.millington@flinders.edu.au

\begin{abstract}
Biogeography is, in essence, the geography of nature or more specifically, the study of the distribution of Earth's life forms at all spatial and temporal scales. This paper traces the historical development of biogeography from ancient times to the twenty-first century, highlights contemporary trends and expansions, and previews future prospects. The cumulative discovery of biogeographic patterns culminated in the development of the theory of evolution - biogeography's greatest contribution to science. The paradigm shift to causal approaches in the early twentieth century led to ecological biogeography emerging as the second pillar of biogeography in addition to historical biogeography. Fostered by the acceptance of plate tectonics, the equilibrium theory of island biogeography, the rapid advancement of new perspectives and methods in historical biogeography, and revolutionary advances in compiling, visualizing, and analyzing spatially explicit information, biogeography evolved into a rigorous science during the second half of the twentieth century. Currently, major active sub-fields are phylogeography, macroecology, and conservation biogeography. Biogeography is on the way to becoming a 'big science', entering an era of increasingly integrative and multi-faceted approaches, increasingly accessible and available data, tools, and techniques, and interdisciplinary collaboration.
\end{abstract}

\section{Key words}

biodiversity - biogeographic patterns - conservation - distribution - ecology - history $\bullet$ interdisciplinarity $\bullet$ macroecology $\bullet$ phylogeography 


\section{Historical overview}

Biogeography aims at understanding the temporal and spatial patterns of life on Earth. A diverse group of scientists have conducted research into the fundamental questions of biogeography - how and why elements of biodiversity (genes, species, communities, ecosystems) vary over the surface of the Earth - for a long time. However, many of these researchers were not aware they were contributing to the discipline of biogeography. Biogeography traditions can be traced back to early theoretical contributions developed within biology, geography, and geology. Accordingly, biogeography as a scientific discipline occupies a mediating position between biosciences (biology, ecology) and geosciences (geography, geology), and exponents of several disciplines pursue biogeographic research, albeit with diverging approaches (Millington et al. 2011).

In the course of a history which stretches from ancient world conceptions of nature and biotic distributions to the beginnings of modern biogeography (commonly associated with Alexander von Humboldt (1769-1859), substantial paradigm shifts have been taking place in biogeography (Blumler et al. 2011). Greek philosophers and scientists are known to have laid the foundations of European scientific culture, and within this biogeography experienced a prehistoric period during Greek Antiquity. Indeed, many of the questions addressed by contemporary biogeographers, e.g., the origin of life and its diversification and global distribution, already puzzled early scholars like Aristotle (384-322 BC) to whom we owe the first deductive insights into meteorology, the taxonomy of organisms and the dynamic character of the Earth. Theophrastus (371-287 BC), who described numerous vegetation types and their distribution when he accompanied Alexander's campaign to India, followed an inductive approach and classified plant groups according to life and growth forms. However, these early efforts were not developed further during
Antiquity. Science during Roman times was characterized by utilitarian thought. The usability of plants and animals took center stage as expressed in Pliny the Elder's (AD 23-79) compendium Historia Naturalis. This is considered a regression compared to the scientific classification of Aristotle (Schmithüsen 1985). Regrettably, the early sources of Chinese and Arabian science, or other ancient civilizations, are barely accessible to 'western' scientists but deserve investigations by historians of science. A first comprehensive account of Chinese vegetation was written by the South Chinese statesman Ji Han in c. AD 300. The Arabian geographer Ibn Khurdadhbih (820-912) depicted the distribution of elephants, rhinos and orangutan, which he considered to be a human species, in his book on kingdoms and transport routes (Beierkuhnlein 2007).

During late Antiquity and early Middle Ages, scholarly endeavour in the west was almost exclusively confined to the cloth. Biomes and habitats with their biotas were taken for granted and accepted as given by God. Due to the authority of biblical texts, intellectual curiosity and research were suppressed in the Christian world, where the 'heathenish' natural sciences faced a wall of hatred and scorn (Mägdefrau 1973). Hardly any scientific progress was achieved in Europe during the Middle Ages, sustained interest in basic issues concerning biotic distribution had to wait until the Renaissance. The Swiss medical doctor Conrad Gesner (1516-1565), who founded the botanical garden in Zurich and described the altitudinal zonation of the European Alps, argued for natural sciences-oriented nature research. The age of European exploration enabled biogeography to develop in tandem with advances in evolutionary biology, ecology and geology (Lomolino et al. 2010). Discoveries around the globe, especially in the New World, challenged prevailing theories on the origin and spread of species, which were still heavily influenced by literal interpretations of the Bible. Georges Louis Leclerc, Comte de Buffon (1707-1788) recognized that 
environmentally similar but isolated regions had distinct assemblages of mammals and birds - an early principle of biogeography later known as Buffon's law. He put forward the influential idea that species must have migrated to other continents under favourable climatic conditions, and were capable of adapting to new environments. Carolus Linnaeus (1707-1778), known as the father of taxonomy and binomial nomenclature, was not only instrumental in the process of species determination and classification, but also accumulated information on species distributions. He further contributed to biogeographic research with his account of Scandinavian vegetation types and a phenological system of climate characterization. Linnaeus' intellectual descendants, such as Willdenow, Engler, Sclater, and Wallace, followed up and augmented his approaches, and established first delineations of the world's floral and faunal provinces or realms (Blumler et al. 2011).

Alexander von Humboldt is generally viewed as the father of phytogeography and credited with being the first to approach the study of vegetation quantitatively. He stressed the importance of environment in determining the distribution of communities, and drew attention to the approach to deduce climatic and edaphic settings from plant physiognomy. In addition, he recognized that latitudinal gradients in vegetation zonation and biodiversity could be identified along elevational gradients, and concluded, based on his surveys on Mt Chimborazo in the Andes, that plants are distributed in altitudinal zones along tropical to arctic climate equivalents. His contributions to climatology, geomorphology and geology were similarly seminal. Humboldt's investigations were a source of inspiration for a series of European phytogeographers such as de Candolle, Schouw, Grisebach, Drude, Warming, and Schimper, who aimed at a global overview and developed a more sophisticated understanding of the world's biomes and their relationship to the environment. Augustin-Pyrame de Candolle (1778-1841) was not only aware of major drivers influencing floristic diversity on islands, but was also the first to emphasize the significance of competition for resources between species in localized habitats - a cornerstone on the way to developing evolutionary and ecological theory (Lomolino et al. 2010).

The early nineteenth century increasingly witnessed the establishment of key elements of ecological biogeography and modern ecology. Scientific endeavours centered around basic questions in biogeography such as the distinctiveness of regional biotas and their origin and spread. In addition, significant progress was made in describing fundamental biogeographic patterns such as horizontal and vertical zonations, endemism or gradients of biodiversity. However, scientists were still searching for testable causal explanations for the patterns that would be widely accepted. A major obstacle to this was a lack of understanding regarding the mutability of the Earth and its biota, e.g., the age of the Earth was still considered a few thousand years only, and the dynamic nature of the Earth's surface and the mechanisms involved in the spread and diversification of species remained poorly understood. It required new discoveries in geology and paleontology to overcome this barrier. That the Earth's climate is highly mutable was a ground-breaking conclusion the Scottish geologist Charles Lyell (1797-1875) and the French geologist and paleobotanist AdolpheThéodore Brongniart (1801-1876) had drawn from analyzing rock strata and their plant fossils. Lyell advocated the dynamic character of the Earth's surface and its biota and suggested continuous depositional, erosional and uplift processes throughout Earth history. The acceptance of his theory of uniformitarianism, the new understanding of the Earth's history and the assumed dynamics of living system inferred from the fossil records paved the way for major advances in biogeography and evolutionary biology. This led to a new view of the world in the mid-nineteenth century which intrinsically tied to the scientific findings of Darwin and Wallace.

Charles Darwin (1809-1882) and Alfred Russell Wallace (1823-1913) independently 
and almost simultaneously developed the theory of evolution through natural selection, incorporating the first theoretical frameworks of species evolution of Jean-Baptiste Lamarck (1744-1829). Much inspired by Humboldt and Lyell, Darwin formed his concept of natural selection and the origin of species on the basis of his explorations, biogeographic observations and extensive collections of specimens during his five-year surveying voyage aboard the Beagle. The patterns he observed were contradictory to conventional thinking and led him to question the still prevailing Creationist doctrine. Reflecting his observations, Darwin postulated that the diversification and adaptation of biotas resulted from natural selection operating over thousands of generations, while the spread and eventual isolation and disjunction is the result of long-distance dispersal. This theory of evolution is arguably one of the most important scientific advances of all time, and perhaps the most important contribution to the field of biogeography (Lomolino et al. 2010). Wallace, considered as the father of zoogeography, developed his version of the theory of evolution which was also influenced by extensive travel in the southern continents and oceanic islands. However, he adhered more strictly to a geographic approach, and developed many basic concepts and principles of biogeography that are still investigated by contemporary biogeographers. Inter alia, he extended the regionalized system of geographic distribution developed earlier by Sclater and produced a detailed map of Earth's biogeographic regions, which still forms the basis of the ecozones and biomes in use today.

The end of the nineteenth century brought to a close a number of defining theoretical achievements in biogeography. In addition to those identified above, they also included Agassiz's theory of the Ice Age and its influences on distributional dynamics of plants and animals throughout the Pleistocene. In a notable theoretical contribution from the geographic side, Friedrich Ratzel (1844-1904) coined the term 'biogeography' (Ratzel 1888). In addition, influenced by Darwin, Haeckel and Wagner, he developed the concept of a general biogeography, which he considered to form an essential link between scientific and human phenomena and thus between physical and human geography. His sudden death in 1904 prevented the completion and publication of his great synthesis on a general biogeography (Müller 1986). In Anglo-American literature, Merriam (1892) used the term for the first time introducing his biogeographic map of North America (Ebach \& Goujet 2006).

\section{Biogeography of the twentieth century}

By the late nineteenth and early twentieth century, increasingly ameliorated classifications of global biotic distributions led to a shift in biogeographic perspective towards processes and mechanisms that drive basic patterns. This paradigm shift initiated the emergence of ecological biogeography and the revival of two of its critical areas - plant physiological ecology and phytosociology. The former focuses on the interaction of plants with the surrounding physical, chemical and biological environments - an approach which became increasingly popular after the zoologist Ernst Haeckel (1834-1919) had coined the term 'oecologie' in 1866. The latter evolved as a basic constituent of plant community ecology, seeking to understand the composition and development of plant assemblages in a given habitat and the interrelationships between species and to their environment. Influential textbooks, e.g., Warming (1896), Schimper (1898), and Schröter (1908), advocated the adoption of a causal approach in vegetation studies, reflecting the emphasis on analyzing vegetation-environment relationships. This approach resulted in the introduction of the ecosystem concept into ecology (Tansley 1935) as well as in novel classifications of plant taxa such as the still commonly used life form classification of Raunkiaer (1934). In Middle Europe, Schimper's treatise, edited by Faber in a third edition in 1935, was the standard work of ecologically-oriented 
plant geography for many decades (Schmitt et al. 2012). This book was continued in a modified version by Heinrich Walter (1898-1989), the most influential exponent of ecophysiologically-based vegetation studies on the European continent throughout the twentieth century. Walter (1962-1968) and Walter and Breckle (1983-1991) incorporated experimental approaches and complemented global vegetation surveys by consolidating findings on the environmental relationships of vegetation types based on advances in physiological plant ecology. Ellenberg and Mueller-Dombois (1967) showed with their global classification system of plant formations that these environmental relationships are well reflected in the physiognomy of plant species.

Simultaneously with the upturn in ecological approaches to biogeography during the early twentieth century, European vegetation scientists felt the need to apply standardized vegetation analysis methods in order to systematically classify plant communities, to evaluate community data ecologically, and map spatial boundaries of communities. The approach led to the development of the north-European (Uppsala school) and the continental-European phytosociology (Zürich-Montpellier school). The latter was intrinsically tied to the name of Josias Braun-Blanquet (1884-1980). The Braun-Blanquet approach, synthesized from previous ideas and methods and elaborated in his textbooks (1928, 1951, 1964), has influenced vegetation science for decades, in particular in German-, French- and Spanish-speaking countries as well as in Russia and most of Asia. Even today, many biogeographers around the world use this detailed system of describing, classifying and mapping communities. For some decades, AngloAmerican vegetation ecologists have wrongly identified the Braun-Blanquet approach as a tool for pure community typology. However, as an ecological approach it goes far beyond the mere description of plant communities (Mueller-Dombois \& Ellenberg 1974; van der Maarel 1975; Dierschke 1994; Kent
2012), and has been the foundation for the accumulation of a particularly rich knowledge of the environments of plant communities and the ecological behavior of plant species on the European continent. For central Europe, this knowledge is summarized in Ellenberg's monumental book on the vegetation ecology of all major natural and manmade vegetation types (Ellenberg \& Leuschner 2010), and in the world's most complete compendium of ecological indicator values of plant species of a defined region (Ellenberg et al. 1992). Ecological knowledge has been complemented by detailed global distribution analyses of the entire Central European flora and related phytogeographic divisions, published by Hermann Meusel, one of the twentieth centuries' leading plant geographer, and his collaborators in an outstanding atlas (Meusel et al. 1965-1992).

In Europe, significant influences on ecological biogeography emanated not only from geographically-oriented branches of biology, but also from biologically-oriented branches of physical geography (i.e. plant geography and zoogeography) whose exponents advocated geographic perspective on regions and landscapes and their biocoenological settings. Plant geographers have dominated over zoogeographers in this regard. Most influential in this respect was Carl Troll (1899-1975), who made important contributions to high mountain ecology and geography and is considered the founder of landscape ecology. He coined this term inspired by applying air photograph interpretation to studies of interactions between environment and vegetation (Troll 1939), and defined it as the study of complex spatial and temporal interactions between biocoenoses and their environmental conditions in a given landscape section (Troll 1966). Neef (1967) and Schmithüsen (1976) expanded on Troll's early concepts by explicitly integrating people and their activities into the continental-European conception of landscape ecology. The concept of a holistic landscape science has had a sustainable impact on interdisciplinary environmental programmes (e.g., the 
UNESCO Man and Biosphere Programme) as well as on contributions from continental-European geography to biogeography which has often focused on human-environment interactions (Schickhoff 1995, 2002, 2011). A similar focus on human-environment interrelationships, albeit developed in a different context, was generated by the Berkeley School of Geography in North America, and provided important contributions to ecological and conservation biogeography (Sauer 1952; Zimmerer 1994; Blumler 2002).

Succession theory and equilibrium/nonequilibrium models dominated the development of ecological biogeography in the Anglo-American domain for most of the twentieth century. Expanding on the work of Warming and Drude, Cowles (1899) suggested a progressive change in community structure and species composition over ecological time. Clements (1916) advanced this concept of plant succession and proposed, in his mono-climax theory, an ordered deterministic view of succession based on the perception that climate determines the order and endpoint for succession in a region which finally leads to a single equilibrium state with a climax community. This view dominated successional theory for many decades, but was soon challenged on theoretical (Gleason 1926) and, later, empirical grounds (Connell \& Slatyer 1977). Gleasonian ecologists negated a deterministic and predictable nature of succession, and advocated a nonequilibrium perspective with a diversity of successional seres and alternative climaxes that are rooted in the tolerances and demands of different species. The controversy, reflecting the Clementsian-Gleasonian debate over community organization in general, has lost some of its sharpness due to the recognition of additional successional pathways besides Clementsian facilitation such as inhibition (Connell \& Slatyer 1977), and the increasing appreciation of the role of disturbance in succession (Pickett \& White 1985). While in the English speaking world the nonequilibrium perspective on vegetation dynamics became widely accepted, European ecologists' views on succession continue to be rather equilibrium-based. However, followers of both views more or less agree that within a region of comparable climatic and edaphic conditions succession is directed towards communities manifested by a predictable set of dominant species. Nevertheless, Gleasonians emphasized the dynamic nature of plant communities in time and space. Continuity in space formed the underlying concept for the continuum research approach started by Curtis and Mclntosh (1951). This approach led to the development of formalized methods of gradient analysis and ordination (Whittaker 1967), from polar ordination (PO) (Bray \& Curtis 1957) and principal component analysis (PCA) (Orlóci 1966) to the currently widely used non-metric multidimensional scaling (NMDS) (Prentice 1977), detrended correspondence analysis (DCA) (Hill \& Gauch 1980), and canonical correspondence analysis (CCA) (Ter Braak 1986). The application of these techniques have permitted major advances in vegetation ecology and ecological biogeography.

During the twentieth century, a trend which has emphasized the theoretical over the descriptive has become evident in AngloAmerican ecological biogeography. The Equilibrium Theory of Island Biogeography (ETIB), developed by MacArthur and Wilson (1967), is arguably the most influential manifestation of this trend. Essentially based on geographic parameters - area size and distance, it explains the role of islands in determining species numbers and distribution, and allows for the prediction of potential species numbers in unsaturated systems - a novel approach that had a wide and continuing influence on biogeography. MacArthur and Wilson proposed an equilibrium between the immigration of new species and the extinction of species already present that is reached over time, and concluded that large islands at short distances from a 'mainland' have a high species diversity while small, distant and more isolated islands have low diversity. Although the ETIB has not been without its critics (reviewed in Blumler et al. 2011) and was in need of expansion (Whittaker 
et al. 2008), it has to be credited inter alia with drawing greater attention to biodiversity in general and promoting the conservation movement by providing the theoretical basis for many conservation strategies. The insular distribution of near-natural landscape elements deserving protection in today's cultural landscapes induced conservationists and land managers to broadly apply the ETIB principles to conservation and the design of nature reserves, albeit with mixed results. MacArthur and Wilson's work was seminal in directing ecological biogeography to a new set of often abstract questions pertaining to distribution patterns, species diversity, coexistence, dispersal, colonization, invasion, and speciation and extinction. Together with other ecologists, they opened the arena for experimental testing of biogeographic concepts (Simberloff \& Wilson 1969) and quantifying and analyzing observations by means of new mathematical approaches (Pielou 1977). Simultaneously, groundbreaking advances in computer technology and related techniques in recent decades (e.g., remote sensing, geographic information systems (GIS), geostatistics and spatial modeling) have tremendously expanded the ability of ecological biogeography to explore and analyze patterns at various spatial and temporal scales. The evolution of gradient analysis and direct/indirect ordination is a vivid illustration of how increasingly sophisticated techniques may evolve by exploiting advances in computing capacity.

These developments in ecological biogeography should not obscure the fact that evolutionary and historical biogeography still dominated the somewhat ill-defined field of biogeography, particularly until the 1960s. Built upon calibrated estimates of the age of the Earth, and the acceptance of unformitarianism and a mutable Earth, both paleontology (concerned primarily with deep-time and evolutionary questions) and Quaternary studies (concerned primarily with environmental reconstruction over the past few million years) progressed significantly in the twentieth century. Paleontologists documented faunal changes on each continent, elucidated long and complex histories of our contemporary continental fauna, and started to analyse the history of faunal movements between land masses and the phylogenies of species groups. Biogeographic syntheses of contributions from paleontology, paleoclimatology, phylogeny, and geology centered around questions of centers of origin of species groups and their subsequent dispersal. Short-lived land bridges, and former or oncejoint continents were hotly debated explanations for the spread of terrestrial organisms from one land mass to another. However, a satisfactory theory-based explanation was still lacking. It was not until the 1960s when the theory of continental drift (plate tectonics) was commonly accepted after geological and geophysical evidence became irrefutable (Briggs 1987) that the theoretical base for the spread of terrestrial organisms was complete. Paleomagnetic evidence of a continent drift over significant distances, the younger age of oceans compared to continents, and the increasing age of oceanic basalts outward from midoceanic ridges were among well-established facts that supported the early, largely rejected version of the theory of continental drift posited and championed by Wegener (1915). Plate tectonic theory had a groundbreaking impact on biogeography by revolutionizing historical explanations of species distribution patterns. Advancing hypotheses about the causes of endemism, disjunction or other biotic distribution patterns was no longer limited by the assumption of largely static landmasses over the course of Earth history. Plate tectonics provided a framework for establishing alternative hypotheses grounded in an ancestral distribution of biota in Laurasia or Gondwana, with vicariance accounting for their disjunction and diversification on previously connected but now isolated landmasses. Together with phylogenetic reconstructions and the fossil record, plate tectonics formed the base for developing and advancing novel conceptual and methodological approaches in historical biogeography in the final decades of the 
twentieth century (Crisci et al. 2003) including panbiogeography (Croizat 1958, 1962; Craw et al. 1999), phylogenetic biogeography (Brundin 1966), vicariance/cladistic biogeography (Nelson \& Platnick 1981; Humphries \& Parenti 1999), and phylogeography (Avise et al. 1987). The latter, in particular, has evolved into a fundamental component of modern biogeography. It is true to say that the acceptance of plate tectonics was essential to the revitalization of biogeography in the last forty or so years.

The twentieth century saw particularly rapid progress in the branch of historical biogeography devoted to the Pleistocene and Holocene Epochs, even before phylogenic methods for evaluating biogeographic patterns had been developed. The events of the past two million years had profound effects on contemporary distributions of plants and animals, in particular repeated glaciations and the advent of humans. A significant upturn of Pleistocene and Holocene biogeography emanated from the development of palynology (fossil pollen and spore analysis). The introduction of quantitative pollen analysis by the Swedish geologist von Post (1918) and the subsequent broad application of this technique yielded results that gave impetus to Quaternary and Tertiary research in different disciplines. Studies of fossil pollen and other fossil plant remains (wood, needles, seeds) from lake sediments, peatlands, flood deposits, and wind-blown sediments have allowed biogeographers to investigate long-term environmental history in detail; and in particular to reconstruct vegetation and climate for the Quaternary. Several benchmark publications summarized the state of the art in pollen-analytical Quaternary research in the mid-twentieth century (Firbas 1949-1952; Godwin 1956; Nejstadt 1957), which is still extensively applied with refined methods and expanded scope (Davis 1966; Seppä \& Bennett 2003; Twiddle 2012). Simultaneously, substantial progress was achieved in the field of dating. The radiocarbon method (Libby 1952) enabled the dating of late- and post-glacial pollen profiles and thus the robust temporal connexion of events in vegetation history over long distances - an invaluable benefit for uncovering vegetation history. In addition, enhancements of other paleoecological methods such as dendrochronology (the dating and studying of annual growth layers in wood) and the analysis of plant macro-remains contributed significantly to the development of historical biogeography. After initial studies by Douglass (1919), dendrochronology has evolved into the most accurate dating technique within the time frame of the past 10,000 years and has expanded to be applied to the dating of archeological ruins, climate change, fire history, insect outbreaks, volcanic eruptions, and glacier movements (Schweingruber 1996; Fritts 2001; Speer 2010).

A retrospective look at the developmental history of biogeography in the twentieth century reveals its accelerated evolution since the 1960s into a rigorous, respected and prosperous science (Lomolino et al. 2010; Millington et al. 2011). In European and North American geography departments, the preceding decades saw a rather languishing subdiscipline of biogeography which was adversely affected by the dominance of geomorphology and the still prevailing disrespect of integrative, interdisciplinary approaches (Taylor 1984). Although biogeography received some representation as indicated by the textbook of Newbigin (1936) dealing with both plants and animals, it was not a core element in geography departments. At the same time, biologists and geologists developed particular emphasis around questions and methods related to the core disciplines of biology, geography and geology, which has led to divergent trends within the broad field of biogeography. Several internal and external factors contributed to the revitalization of biogeography since the mid1960s, which occurred almost simultaneously in North American and European scientific communities. Arguably the most stimulating process was the awakening of environmentalism and the upturn of the ecology and nature conservation movement which prompted the 
development of more integrative perspectives and holistic approaches. This in turn initiated the weakening and partial breakdown of boundaries between disciplines of environmental sciences, and the design of joint and multi-disciplinary curricula and courses at universities. New posts for teaching subject matters of biogeography were created (not always called biogeography though), facilitated by the expansion of existing and the foundation of new universities in Europe and North America as a response to the increasing rates of higher education participation. The re-emergence of biogeography, then sympathetically commented on by geographers (Edwards 1964; Watts 1978) and biologists (e.g., Nelson 1978), was also reflected in the publication of respective textbooks which saw its peak time in the late 1960s and 1970s (Millington et al. 2011). At the same time, the Journal of Biogeography, which has evolved into the leading forum for biogeographic research and thinking, was founded (1974), followed by the establishment of biogeography research or specialty groups in national geography associations (e.g., UK: 1974, US: 1981, Germany: 1998), and on the international level (Biogeography and Biodiversity Commission of the International Geographical Union: 1996; International Biogeography Society: 2001).

\section{Contemporary biogeography: recent developments and expansions}

Expansion, advancing maturity and vitality characterizes the developmental of biogeography in recent decades; a trend that continues. The number of publications in the field is conclusive evidence. The number of books on biogeography grew from a few in the 1960s to over 200 today, the number of journal articles on biogeography indexed in global journal databases (with 'biogeography' as keyword) has increased five-fold since 1990 (Lomolino et al. 2010). Starting with four issues a year in 1974, the Journal of Biogeography is now published at the rate of 12 issues a year with the number of articles appearing in each volume increasing from about 20 to about 200. In 1991 and 1998 respectively, the allied journals Global Ecology and Biogeography and Diversity and Distributions were launched, with each showing an increase in number of articles published as well as in journal citation impact factors. Another research journal, 'Ecography', which covers all aspects of biogeography, has had similar levels of success in recent years. Moreover, a broad range of ecological, evolutionary, conservation, and geography-based journals provide further evidence of a steady increase in biogeography-related research.

The achievements and perspectives that emerged during the closing decades of the twentieth century (see above) have generated increasing diversification of the field, which is arguably the most important driving force for the burgeoning increase in number of publications and for the raised awareness of biogeography as a rigorous science. The present scope of biogeography is enormous. The diversification in geographic coverage, taxonomic range, methodological variety and conceptual approach - already commented on in the 1990s and termed 'adaptive radiation' (Meadows 1997) - has continued. The traditional division into ecological and historical biogeography has been somewhat superseded by the differentiation into subdisciplines such as island biogeography, marine biogeography, ecogeography, macroecology, dispersal biogeography, vicariance/cladistic biogeography, panbiogeography, phylogeography, spatial, analytical, and applied or conservation biogeography. At the same time, the trend of isolation and specialization of descendant subdisciplines aggravates the latent identity crisis faced by biogeography. This is exacerbated by the fact that the widely divergent issues are studied using different methodologies across the natural sciences. The increasingly broad arena of biogeography implies that it is impossible for a single biogeographer to understand and follow completely all aspects of the field - the 'ivory archipelago' situation which is, however, 
characteristic for the entire spectrum of contemporary academia (Millington et al. 2011). On the other hand, it can be argued that the interdisciplinary nature of biogeography is the discipline's greatest distinction and strength. Added to this is the fact that modern biogeography has a unifying question - the variation of all life-forms across spatial and temporal dimensions - which arguably leads to a reintegration of conceptual lineages, and to potential novel fruitful collaborations and conceptual syntheses.

Some of the descendant subdisciplines have grown more vigorously than others and continue to thrive and expand. A pertinent example is phylogeography which has enjoyed an explosive rate of growth and is now considered a dominant force in modern historical biogeography (Lomolino et al. 2010; Posadas et al. 2013). Based on mitochondrial DNA (animals) and chloroplast DNA (plants) analyses, phylogeography has developed tools to reconstruct phylogenetic and population genetic structure across gene lineages within species and among closely related species, thereby generating novel insights into the evolutionary and geographic responses of species and populations to dynamics in Earth history (Avise 2009; Riddle 2011). The impact of phylogeography is revolutionary from both geographic and biological perspectives. For the first time, biogeographers are able to correlate evolutionary patterns of divergence of organisms with patterns of environmental change over the past several million years, and thus are in the position to overcome the lack of integration between historical biogeography and ecological biogeography that continued until the 1990s (Cox \& Moore 2010). Biologists consider phylogeography to have evolved into one of the most integrative disciplines in all of biology since phylogeographic estimates and model testing can be potentially combined with studies of ecological speciation and radiation, ecological niche models, community assembly models, as well as spatial analysis of quantitative trait variation and natural selection (Hickerson et al. 2010).
Without any doubt phylogeography will continue to play an important role in the expansion of biogeography and its integration with novel approaches and themes. Further recent developments in historical biogeography include the general shift from pattern-based methods to so-called event-based biogeography in reconstructing ancestral distributions (Ronquist \& Sanmartin 2011), accompanied by the development of parametric methods for reconstructing range evolution and divergence times (reviewed in Wen et al. 2013). Historical biogeography has increasingly become an integrative science which continues to intrigue scientists from across disciplines, e.g., exemplified recently by the widely noticed updated map of zoogeographic regions (Holt et al. 2013) which incorporates phylogenetic information in the delineation of zoogeographic units.

Within the purview of ecological biogeography, a relatively new disciplinary area termed macroecology has developed rapidly in the past two decades. The term was coined for describing a multi-scale approach to analyze the assembly and structure of biotas by applying questions posed by ecologists to spatial and temporal scales usually studied by biogeographers and macroevolutionists (Brown \& Maurer 1989). Expanding the spatial and temporal scale of traditional ecological research, together with the emphasis on statistical pattern analysis rather than experimental manipulation, is its basic difference with ecology. Macroecology aims at investigating general patterns of ecological systems that emerge at large spatial and temporal scales, and at understanding underlying mechanisms by focusing on statistical distributions of variables across these scales, and among large numbers of equivalent ecological units (Brown 1995; Gaston \& Blackburn 1999). It thus adopts a large-scale view of the world that is predicated on early statistical approaches focusing on the distribution of attributes among species (Willis 1922), and has echoes of earlier approaches advocated by MacArthur (1972). In elucidating patterns in biological diversity at large spatial scales, 
macroecology overlaps with other subbranches of biogeography such as ecogeography (referring to very regular geographic gradients in the characteristics of organisms; Gaston et al. 2008) and aerography (referring to sizes, shapes, and internal structure of geographic ranges; Gaston 2003), but is distinct in emphasizing extant statistical patterns while exploring a domain where the fields of ecology, biogeography, paleontology and macroevolution come together (Brown 1995; Gaston \& Blackburn 2000). Macroecology offers a novel, comprehensive perspective to ecological complexity, and aims at searching for general laws, theories and principles relating to respective processes and resulting patterns (Blackburn \& Gaston 2003; Kent 2005).

In a similar vein to phylogeography, macroecology has been taking an increasingly significant place in the biogeography research agenda, not least because of developments in data recording, processing technologies and computing power. Progress has been achieved in documenting empirical patterns of biodiversity across scales of space and time and at different levels of biological organization (Brown 2014). The number of publications has increased dramatically, with recurrent topics such as species richness patterns, range size distributions and variations, metabolic scaling theory, phylogenetic relationships, and human impact and biological conservation. The key journal Global Ecology and Biogeography (which is subtitled A Journal of Macroecology) has increased its journal impact factor from 1.02 in 2000 to 7.22 in 2012 and reached the highest ranking in the physical geography group in 2012 (and 8th in the much larger ecology group). From a biological perspective, macroecology has established itself as a major line of biological research over the past two decades (Beck et al. 2012), and geographers now consider it a very significant part of physical geography (Kent 2007), without, however, providing many significant published contributions.

A third emerging sub-branch experiencing rapid growth in recent years is conservation biogeography, which as an applied and interdisciplinary science involves the application of biogeographic principles, theories and analyses (those concerned with the distributional dynamics of taxa individually and collectively) regarding biodiversity conservation (Whittaker et al. 2005; Richardson \& Whittaker 2010). It is beyond dispute that biogeographic science, deeply rooted in the geographic, ecological and evolutionary context of nature, is in a position to make significant contributions to the conservation of biodiversity. This had already become obvious in the early emergence phase of environmentalism and the modern conservation movement in the second half of the twentieth century, when biogeographic analysis and conservation guidance were combined to design protected area networks (Dasmann 1972) or in the context of applying island biogeography to the problem of habitat fragmentation (Diamond 1975). Thus, biogeography was central to early theory formation within conservation biology, which became established as an applied research discipline in parallel with the expansion of nature conservation movement during the 1970s and 1980s. Initially, it was narrowly defined as being concerned with the application of population biology, taxonomy and genetics to problems of biodiversity conservation. Recognizing the need to counteract complex real-world problems with integrative, interdisciplinary approaches, the scope of conservation biology expanded to incorporate a broader range of disciplines including biogeography and the social sciences. The term 'conservation biogeography' was first coined by Grehan (1993) to stress the significance of large-scale spatial and temporal perspectives in facing the biodiversity crisis. Meanwhile, conservation biogeography has emerged as a distinctive and thriving sub-field of conservation biology, and of biogeography focusing on pattern and process at coarser scales of analysis (landscape, regional, global) and contributing scientific guidance for conservation planning and effective biodiversity management (Ladle \& Whittaker 2011). It gained huge 
momentum after being the focus of international biogeography conferences (Lomolino \& Heaney 2004), its formal definition (Whittaker et al. 2005), and featuring prominently as the subtitle of a key journal (Richardson 2005). Prominent areas of research in conservation biogeography and recurrent themes of journal contributions include inter alia the biogeography of degradation (landuse transformation, habitat fragmentation, homogenization and other human-induced impacts), climate change impacts, species distribution modeling, processes (colonization, dispersal, invasion, disturbance, extinction, range expansion, resilience, speciation), inventory, mapping and data issues, characterizing biotas (conservation status, diversity indices and patterns, rarity, endemism, range size), conservation planning, and methodological issues (Richardson \& Whittaker 2010). Major contributions to human impact and conservation planning issues in conservation biogeography emanate from geographers who originally have a greater affinity to the ecology-society nexus and who frame much of empirical work and many theoretical advances regarding human-environment interactions (Lambin \& Geist 2006; Turner II et al. 2007; Millington \& Jepson 2008).

Apart from the sub-fields of phylogeography, macroecology, and conservation biogeography, the pace of research continues to increase in other, often overarching branches of biogeography. A case in point is island biogeography, which is undergoing a resurgence. A range of interrelated systematic, ecological, and evolutionary studies are contributing to the formation of concepts and theories (Whittaker et al. 2008; Losos \& Ricklefs 2010) that can be tested on a broader scale since islands serve as a model for isolated ecosystems in terrestrial environments. A new synthesis in island biogeography theory is currently emerging that might comprehensively explain the assembly and disassembly of island biotas. The last decade has also witnessed cumulative advances in marine biogeography. Oceanographers and marine biogeographers increasingly provide novel insights into the three-dimensional differentiation of marine environments, their paleoecology, and the spatial and temporal dynamics of marine biotas (Crame 2004; Witman \& Roy 2009; Tittensor et al. 2010). Although marine biogeography is now a recognized sub-discipline, a better integration of marine studies into biogeographic literature is needed but still impeded by the challenges of conducting marine research and the resultant, less detailed, datasets compared to those for terrestrial organisms (Dawson et al. 2013). Yet another rapidly developing field comprises species distribution modeling and ecological niche modeling that apply niche theory to current questions about real and potential spatial distributions of species in the past, present, and future (Peterson et al. 2011). Over the past 15 years, substantial increases in availability of species' occurrence data and in multi-scale information regarding environmental variables led niche-based species distribution modeling to become a very active and rapidly advancing front in analytical biogeography (Guisan \& Thuiller 2005; Araújo \& Guisan 2006; Araújo \& Peterson 2012). It is increasingly applied in studies of conservation biology, ecology, palaeoecology, and wildlife management. A common and policy-relevant field of application is to predict potential changes in species distributions under climate and land-use change scenarios. The use of species distribution models for climate change modeling of biodiversity has been substantially improved in recent years, and is considered a powerful tool in conservation biogeography (Thuiller et al. 2008, 2011; Franklin 2010; see also Sinclair et al. 2010). Other recent modeling studies focus on predicting range expansions in the context of species invasions (e.g., Villemant et al. 2011) and disease transmissions (Gonzalez et al. 2010). In addition, species distribution modeling has contributed significantly to the challenge of linking ecological and historical biogeography. E.g., it can be applied to reconstruct Pleistocene refugia and paleodistributions (Svenning et al. 2008; Maguirea \& Stigall 2009; Wiens 2011), or to perform 
comparative paleo-niche modeling analyses across multiple lineages of taxa to elucidate the formation of large-scale disjunctions (Wen et al. 2013).

A meaningful indicator of recent developments and expansions in biogeography is the transformation of key journals and key symposia with regard to contents. A recent evaluation of word clouds for Journal of Biogeography articles between 1979 and 2013 yielded major shifts in the importance of terms and topics (Whittaker 2014). Some topic areas such as island biogeography, biogeographic regions, and Quaternary/Pleistocene environmental and biogeographic change were consistently represented throughout the past four decades. Dispersal and evolution, as well as topics such as migration, extinction, speciation, diversification, diversity gradients, and treeline studies have likewise remained core features in journal papers. Distributional modeling and range shifts exhibit an increase in importance over time. Most distinct, however, has been the shift in relevance of the term phylogeography, reflecting its emergence as both a technique and as a research programme. The upgrading of macroecology, invasion biology and conservation biogeography is reflected in the publication of the allied journals (see above) which have a strong focus on these topics and now accommodate the majority of the respective papers previously published in the Journal of Biogeography. These burgeoning topics are reflected in the latest editions of long-established textbooks (e.g., Cox \& Moore 2010; Lomolino et al. 2010). Another shift over time concerns spatial and temporal scale. Formerly predominant 'landscape scale' studies have been increasingly replaced by studies conducted at regional and global scale, while topics have increasingly covered deeper time-scales beyond the Quaternary.

These contemporary debates and topics are reflected in the conception of recent key symposia. At the 6 th biennial meeting of the International Biogeography Society (IBS) in Miami, 2013, special symposia were held on island biogeography, the biogeography of traits, the convergence of conservation paleontology and biogeography, and predicting species and biodiversity in a warmer world. Contributed paper sessions were organized on global change biogeography, phylogeography, marine biogeography, the biogeography of the Anthropocene, island biogeography, neotropical biogeography, historical and paleobiogeography, conservation biogeography, and global-scale biogeography. This spectrum of topics mirrors the overall orientation of the global 'community of practice' biogeographers. More specifically, a group of organizers, session chairs, and discussants (Dawson et al. 2013) identified a set of emerging themes from this meeting that might indicate, at least partially, the current frontiers of biogeography. These topics include (I) genes, traits, and patterns of biodiversity, (II) tropical biogeography, (III) marine and freshwater biogeography, (IV) the challenge of integrating information, $(V)$ challenges within integration, (VI) model systems, and (VII) infectious diseases.

\section{Outlook: Biogeography and the future discovery and conservation of biodiversity}

Reviewing the development of biogeography in the recent past, in particular over the last decade, it is obvious that it has expanded significantly in breadth and vitality. Moreover, it will likely play an increasingly significant role in a range of future research agendas: biogeography is now on the way to becoming a 'big science'. Specifically, it is entering an era characterized by increasingly integrative and multi-faceted approaches; increasingly available data, tools, and techniques; and interdisciplinary collaboration. New developments in data availability have resulted in increased size and complexity of data sets, advanced numerical modeling is required to analyse these. Published papers are characterized by ever-increasing complexity, often to an extent that not all aspects of the analyses can be understood by a single researcher. The elevated complexity of articles is mirrored 
by the trend of increased number of authors per paper in key journals over the last 15 years (Whittaker 2014). One can thus expect a further expansion of the physical and conceptual dimensions of biogeography, a science whose frontiers are being continuously explored, advanced, and redefined (Lomolino et al. 2010).

This new disciplinary development opens up several new vistas in terms of scientific challenges and opportunities (Wen et al. 2013; Dawson et al. 2013), as well as the significance of biogeography for science policy. The field has become increasingly integrative and has established close links to systematics, ecology, paleontology, physical and human geography, and conservation biology. Increased data availability tools from geostatistics and GIS will enable biogeographers not only to re-evaluate global and local patterns, and long-standing theories. But it will also (I) facilitate constructing multidimensional syntheses of geography, phylogeny, ecology, geology, paleontology, physiology, and genomics; and (II) expand the dimensions of biogeography, e.g., once the three-dimensional dynamics of marine environments is better understood and marine biogeography is fully integrated. Continued progress in our understanding of biodiversity patterns at regional and global scales may be expected from the upturn of macroecological approaches which will particularly benefit from advances in the quality and resolution of biogeographic data. Web-based biodiversity informatics initiatives such as the recently launched 'Map of Life'-platform (Jetz et al. 2012), which aims to build up a globally integrated spatial biodiversity infrastructure, have the potential to provide unprecedented access to spatio-temporal species information, and to overcome limitations set by the Wallacean shortfall - the lack of knowledge of geographical distributions and geographic variation in the traits of most species. The continuing development of automated species identification systems (Cope et al. 2012) will further enrich the biogeographers' tool kit in this respect, and will be of increasing significance given the global shortage of expert taxonomists.

Innovations in historical biogeography will provide exciting enhancements of our knowledge of past, present, and future patterns of biodiversity, e.g., phylogeographic studies may increasingly reveal how climate, geography, and ecological interactions determine and interact with community composition and evolution. In combination with advanced molecular dating, novel insights into species diversification across time and space will be generated. Combining methods of historical biogeography with ecological niche modeling offers innovative applications in biodiversity conservation and management, e.g., when priority areas for conservation have to be identified. Similarly, applying predictive models from island biogeography and recent advances in island theory to the problem of ongoing fragmentation of ecosystems and the creation of habitat islands will become increasingly helpful for understanding and conserving near-natural remnants within cultural landscapes. In general, conservation biogeography has come of age and developed the potential to significantly contribute to conservation problems caused by climate and land-use change, e.g. by disentangling human-environment interactions, and providing predictions about the fate of key species and ecosystems over the coming decades.

Life on Earth is currently experiencing unprecedented human impacts and a rapid and dramatic transformation. Given the increasing rate at which so many levels of biodiversity are being damaged and lost, biogeography has many important applications. Understanding and predicting the ecological implications of anthropogenic impacts on species and landscapes, and contributing to appropriate responses is a metric of biogeography that will have increased importance and societal relevance in the twenty-first century. Nonetheless, biogeography still suffers from a low public profile and has very little presence in the public sphere (Ladle 2008). The term 'biogeography' is almost invisible in newspaper coverage globally despite the fact that biogeographic 
subject matter is ubiquitous in public debates and well covered in electronic and popular media. As professional biogeographers we are convinced that biogeography matters more

\section{References}

Araújo M.B., Guisan A., 2006. Five (or so) challenges for species' distribution modelling. Journal of Biogeography, vol. 33, no. 10, pp. 1677-1688.

Araújo M.B., Peterson A.T., 2012. Uses and misuses of bioclimatic envelope modeling. Ecology, vol. 93, no. 7, pp. 1527-1539.

AvISE J.C., 2009. Phylogeography: Retrospect and prospect. Journal of Biogeography, vol. 36, no. 1, pp. 3-15.

Avise J.C., Arnold J., Ball R.M., Bermingham E., Lamb T., Neigel J.E., Reeb C.A., Saunders N.C., 1987. Intraspecific phylogeography: The mitochondrial-DNA bridge between populationgenetics and systematics. Annual Review of Ecology and Systematics, vol. 18, no.1, pp. 489-522.

Beck J., Ballesteros-MejaA L., Buchmann C.M., Dengler J., Fritz S.A., Gruber B., Hof C., Jansen F., Knapp S., Kreft H., Schneider A.K., Winter M., Dormann C.F., 2012. What's on the horizon for macroecology? Ecography, vol. 35, no. 8, pp. 673-683.

BeierkuHnlein C., 2007. Biogeographie. Stuttgart: Verlag Eugen Ulmer.

BLACKBURN T.M., GASTON K.J. (eds.), 2003. Macroecology: concepts and consequences. Cambridge: Cambridge University Press.

BLUMLER M.A., 2002. Environmental management and conservation [in:] A.R. Orme (ed.), Physical Geography of North America. Oxford: Oxford University Press, pp. 516-535.

Blumler M.A., Cole A., Flenley J., SChickhoff U., 2011. History of biogeographical thought [in:] A.C. Millington, M.A. Blumler, U. Schickhoff (eds.), The SAGE handbook of biogeography. London: SAGE Publications, pp. 23-42.

Braun-Blanquet J., 1928, 1951, 1964. Pflanzensoziologie. Grundzüge der Vegetationskunde. 1st edn. Berlin: Springer, 2nd edn. Vienna: Springer, 3rd edn. Vienna-New York: Springer. than ever, both in the discovery and in the conservation of biodiversity, therefore we have to communicate more effectively and revise public perceptions of the discipline.

Bray J.R., Curtis J.T., 1957. An ordination of the upland forest communities of southern Wisconsin. Ecological Monographs, vol. 27, no. 4, pp. 325-349.

BRIGGS J.C., 1987. Biogeography and plate tectonics. Amsterdam: Elsevier.

Brown J.H., 1995. Macroecology. Chicago: University of Chicago Press.

Brown J.H., 2014. Why are there so many species in the tropics? Journal of Biogeography, vol. 41, no. 1, pp. 8-22.

Brown J.H., Maurer B.A., 1989. Macroecology: The division of food and space among species on continents. Science, vol. 243, no. 4895, pp. 1145-1150.

BRUNDIN L.K., 1966. Transantarctic relationships and their significance, as evidenced by chironomid midges: With a monograph of the subfamilies Podonominae and Aphroteniinae and the austral Heptagyiae. Kungliga Svenska Vetenskapsacademiens Handlingar, ser. 4, vol. 11, no. 1, Stockholm: Almqvist \& Wiksell.

Clements F.E., 1916. Plant succession: An analysis of the development of vegetation. Carnegie Institution of Washington publication, 242, Washington: Carnegie Institute of Washington.

Connell J.H., Slatyer R.O., 1977. Mechanisms of succession in natural communities and their role in community stability and organization. American Naturalist, vol. 111, no. 982, pp. 1119-1144.

Cope J.S., Corney D., Clark J.Y., Remagnino P., WILKIN P., 2012. Plant species identification using digital morphometrics: A review. Expert Systems with Applications, vol. 39, no. 8, pp. 7562-7573.

COWLES H., 1899. The ecological relations of the vegetation of the sand dunes of Lake Michigan. Botanical Gazette, vol. 27, no. 2, pp. 95-117, no. 3 , pp. $167-202$, no. 4 , pp. 281-308, no. 5, pp. $361-391$. 
Cox C.B., Moore P.D., 2010. Biogeography. An ecological and evolutionary approach. 8th ed. New York: J. Wiley \& Sons.

Crame J.A., 2004. Pattern and process in marine biogeography [in:] M.V. Lomolino, L.R. Heaney (eds.), Frontiers of biogeography: new directions in the geography of nature. Sunderland, MA: Sinquer Associates, pp. 272-292.

Craw R.C., Grehan J.R., Heads M.J., 1999. Panbiogeography: Tracking the history of life. Oxford: Oxford University Press.

Crisci J.V., Katinas L., Posadas P., 2003. Historical biogeography. Cambridge, MA: Harvard University Press.

Croizat L., 1958. Panbiogeography or an introductory synthesis of zoogeography, phytogeography and geology; with notes on evolution, systematics, ecology, anthropology, etc. Caracas: published by the autor.

CroizAT L., 1962. Space, time, form: The biological synthesis. Caracas: published by the author.

CuRTIS J.T., McINTOSH R.P., 1951. An upland forest continuum in the prairie-forest border region of Wisconsin. Ecology, vol. 32, no. 3, pp. 476-496.

DASMANN R.F., 1972. Towards a system for classifying natural regions of the world and their representation by national parks and reserves. Biological Conservation, vol. 4, no. 4, pp. 247-255.

Davis M.B., 1966. Determination of absolute pollen frequency. Ecology, vol. 47, no. 2, pp. 310-311.

Dawson M.N., Algar A.C., Antonelli A., Dávalos L.M., Davis E., Early R., Guisan A., Jansson R., Lessard J.P., Marske K.A., McGuire J.L., Stigall A.L., Swenson N.G., Zimmermann N.E., GAVIN D.G., 2013. An horizon scan of biogeography. Frontiers of Biogeography, vol. 5, no. 2, pp. 130-157.

DiAmOND J.M., 1975. The island dilemma: Lessons of modern biogeographic studies for the design of natural preserves. Biological Conservation, vol. 7, no. 2, pp. 129-146.

DieRSCHKE H., 1994. Pflanzensoziologie. Stuttgart: Verlag Eugen Ulmer.

DouglasS A.E., 1919. Climatic cycles and treegrowth. 289, Washington: Carnegie Institute of Washington.

Ebach M.C., Goujet D.F., 2006. The first biogeographical map. Journal of Biogeography, vol. 33, no. 5, pp. 761-769.
EDWARDS K.C., 1964. The importance of biogeography. Geography, vol. 49, no. 2, pp. 85-97.

Ellenberg H., LeusChner C., 2010. Vegetation Mitteleuropas mit den Alpen in ökologischer, dynamischer und historischer Sicht. Stuttgart: Eugen Ulmer Verlag.

Ellenberg H., Mueller-Dombois D., 1967. Tentative physiognomic-ecological classification of plant formations of the Earth. Berichte des Geobotanischen Instituts der ETH, 37. Zürich: Stiftung Rübel, pp. 21-55.

Ellenberg H., Weber H.E., Düll R., Wirth V., WerNeR W., PAulissen D., 1992. Zeigerwerte von Pflanzen in Mitteleuropa. Scripta Geobotanica, 18, Göttingen: Goltze.

FIRBAS F., 1949-1952. Spät- und nacheiszeitliche Waldgeschichte Mitteleuropas nördlich der Alpen. Vol. 1: Allgemeine Waldgeschichte. Vol. 2: Waldgeschichte der einzelnen Landschaften. Jena: Gustav Fischer Verlag.

FrankLIN J., 2010. Moving beyond static species distribution models in support of conservation biogeography. Diversity and Distributions, vol. 16, no. 3, pp. 321-330.

FRITTS H.C., 2001. Tree rings and climate. Caldwell, NJ: Blackburn Press.

GASTON K.J., 2003. The structure and dynamics of geographic ranges. Oxford: Oxford University Press.

Gaston K.J., BLaCKBURn T.M., 1999. A critique for macroecology. Oikos, vol. 84, no. 3, pp. 353-368.

Gaston K.J., Blackburn T.M., 2000. Pattern and process in macroecology. Oxford: Wiley-Blackwell.

Gaston K.J., Chown S.L., Evans K.L., 2008. Ecogeographical rules: elements of a synthesis. Journal of Biogeography, vol. 35, no. 3, pp. 483-500.

GLEASON H.A., 1926. The individualistic concept of the plant association. Bulletin of the Torrey Botanical Club, vol. 53, no. 1, pp. 7-26.

GodwIN H., 1956. The history of the British flora. A factual basis for phytogeography. Cambridge: Cambridge University Press.

González C., Wang O., Strutz S.E., González-Salazar C., Sánchez-Cordero V., Sarkar S., 2010. Climate change and risk of Leishmaniasis in North America: Predictions from ecological niche models of vector and reservoir species. PLoS Neglected Tropical Diseases, vol. 4, no. 1, http://www.plosntds.org/ 
article/info\%3Adoi\%2F10.1371\%2Fjournal. pntd.0000585 [26 May 2014].

GreHAN J.R., 1993. Conservation biogeography and the biodiversity crisis: A global problem in space/time. Biodiversity Letters, vol. 1, no. 5, pp. 134-140.

Guisan A., Thuiller W., 2005. Predicting species distribution: Offering more than simple habitat models. Ecology Letters, vol. 8, no. 9, pp. 993-1009.

Hickerson M.J., Carstens B.C., Cavender-Bares J., Crandall K.A., Graham C.H., Johnson J.B., Rissler L., Victoriano P.F., Yoder A.D., 2010. Phylogeography's past, present, and future: 10 years after Avise, 2000. Molecular Phylogenetics and Evolution, vol. 54, no. 1, pp. 291-301.

Hill M.O., GauCh H.G., 1980. Detrended correspondence analysis, an improved ordination technique. Vegetatio, vol. 42, no. 1-3, pp. 47-58.

Holt B.G., Lessard J.P., BorregaArd M.K., Fritz S.A., Araújo M.B., Dimitrov D., Fabre P.H., Graham C.H., Graves G.R., Jønsson K.A., Nogués-Bravo D., Wang Z., Whittaker R.J., FJeldSA J., RahbeK C., 2013. An update of Wallace's zoogeograohic regions of the world. Science, vol. 339, no. 6115, pp. 74-78.

Humphries C.J., Parentı L.R., 1999. Cladistic biogeography. Interpreting Patterns of Plant and Animal Distributions. 2nd ed. Oxford: Clarendon Press.

Jetz W., McPherson J.M., Guralnick R.P., 2012. Integrating biodiversity distribution knowledge: toward a global map of life. Trends in Ecology and Evolution, vol. 27, no. 3, pp. 151-159.

KENT M., 2005. Biogeography and macroecology. Progress in Physical Geography, vol. 29, no. 2, pp. 256-264.

KENT M., 2007. Biogeography and macroecology: now a significant component of physical geography. Progress in Physical Geography, vol. 31, no. 6, pp. 643-657.

KENT M., 2012. Vegetation description and analysis. A practical approach. 2nd ed. Chichester: Wiley-Blackwell.

LADLE R.J., 2008. Catching fairies and the public representation of biogeography. Journal of Biogeography, vol. 35, no. 3, pp. 388-391.

Ladle R.J., WhitTaker R.J. (eds.), 2011. Conservation biogeography. Chichester: Wiley-Blackwell.
Lambin E.F., Geist H.J. (eds.), 2006. Land-use and land-cover change. Local processes and global impacts. Berlin-Heidelberg: Springer.

LIBBY W.F., 1952. Radiocarbon dating. Chicago, IL: University of Chicago Press.

Lomolino M.V., Heaney L.R. (eds.), 2004. Frontiers of biogeography: new directions in the geography of nature. Sunderland, MA: Sinquer Associates.

Lomolino M.V., Riddle B.R., Whittaker R.J., Brown J.H., 2010. Biogeography. Sunderland, MA: Sinauer Associates.

Losos J.B., Ricklefs R.E. (eds.), 2010. The theory of island biogeography revisited. Princeton, NJ: Princeton University Press.

MacArthur R.H., 1972. Geographical ecology: Patterns in the distribution of species. New York: Harper and Row.

MacArthur R.H., Wilson E.O., 1967. The theory of island biogeography. Princeton, NJ: Princeton University Press.

Mägdefrau K., 1973. Geschichte der Botanik. Leben und Leistung grosser Forscher. Stuttgart: Gustav Fischer Verlag.

Maguirea K.C., Stigall A.L., 2009. Using ecological niche modeling for quantitative biogeographic analyses: A case study of Miocene and Pliocene Equinae in the Great Plains. Paleobiology, vol. 35, no. 4, pp. 587-611.

Meadows M.E., 1997. Biogeography - adaptive radiation of a discipline. Progress in Physical Geography, vol. 21, no. 4, pp. 583-592.

Merriam C.H., 1892. The geographical distribution of life in North America: With special reference to the Mammalia. Proceedings of the Biological Society of Washington, 7, Washington: Biological Society of Washington.

Meusel H., Jäger E., Weinert E., 1965-1992. Vergleichende Chorologie der zentraleuropäischen Flora. 3 vols., Jena: Gustav Fischer.

Millington A.C., Jepson W.E.J. (eds.), 2008. Land change science in the tropics: Changing agricultural landscapes. New York: Springer.

Millington A.C., Blumler M.A., Schickhoff U., 2011. Situating contemporary biogeography [in:] A.C. Millington, M.A. Blumler, U. Schickhoff (eds.), The SAGE handbook of biogeography. London: SAGE Publications, pp. 1-18. 
Mueller-Dombois D., Ellenberg H., 1974. Aims and methods of vegetation ecology. New York: J. Wiley \& Sons.

Müller G.H., 1986. Das Konzept der "Allgemeinen Biogeographie" von Friedrich Ratzel (1844-1904). Eine Übersicht. Geographische Zeitschrift, vol. 74, no. 1, pp. 3-14.

Neef E., 1967. Die theoretischen Grundlagen der Landschaftslehre. Leipzig-Gotha: VEB Verlag Haack.

NejSTADT M.I., 1957. Waldgeschichte und Paläogeographie der UdSSR im Holozän. Moskau (in Russian).

Nelson G., 1978. From Candolle to Croizat: Comments on the history of biogeography. Journal of the History of Biology, vol. 11, no. 2, pp. 269-305.

Nelson G., Platnick, N., 1981. Systematics and biogeography: Cladistics and vicariance. New York: Columbia University Press.

NeWBIGIN M.I., 1936. Animal and plant geography. London: Methuen and Co. Ltd.

OrLÓCI L., 1966. Geometric models in ecology. 1. The theory and application of some ordination methods. Journal of Ecology, vol. 54, no.1, pp. 193-215.

Peterson A.T., Soberón J., Pearson R.G., Anderson R.P., Martínez-Meyer E., Nakamura M., Araújo M.B., 2011. Ecological niches and geographic distributions. Princeton, NJ: Princeton University Press.

Pickett S.T.A., White P.S., 1985. The ecology of natural disturbance and patch dynamics. San Diego: Academic Press.

Pielou E.C., 1977. Mathematical ecology. New York: J. Wiley \& Sons.

Posadas P., Grossi M.A., Ortiz-Jaureguizar E., 2013. Where is historical biogeography going? The evolution of the discipline in the first decade of the 21st century. Progress in Physical Geography, vol. 37, no. 3, pp. 377-396.

Prentice I.C., 1977. Non-metric ordination models in ecology. Journal of Ecology, vol. 65, no. 1, pp. 85-94.

Ratzel F., 1888. Ueber Die Anwendung des Begriffs "Oekumene" auf geographische Probleme der Gegenwart. Berichte und Verhandlungen der Königlichen Sächsischen Gesellschaft der Wissenschaften Leipzig. Philosophisch-Historische Classe, 40, pp. 137-180.
Raunkiaer C., 1934. The life form of plants and statistical plant geography. Oxford: Clarendon Press.

Richardson D.M., 2005. Diversity, distributions and conservation biogeography. Diversity and Distributions, vol. 11, no. 1, pp. 1-2.

Richardson D.M., WhitTaker R.J., 2010. Conservation biogeography - foundations, concepts and challenges. Diversity and Distributions, vol. 16, no. 3, pp. 313-320

RIDDLE B.R., 2011. The expanding role of phylogeography [in:] A.C. Millington, M.A. Blumler, U. Schickhoff(eds.), The SAGE handbook of biogeography. London: SAGE Publications, pp. 99-117.

Ronquist F., Sanmartin I., 2011. Phylogenetic methods in biogeography. Annual Review of Ecology, Evolution, and Systematics, 42, pp. 441-464.

SAUER C.O., 1952. Agricultural origins and dispersals. New York: American Geographical Society.

SCHICKHOFF U., 1995. Himalayan forest-cover changes in historical perspective. A case study in the Kaghan Valley, northern Pakistan. Mountain Research and Development, vol. 15, no. 1, pp. 3-18.

SCHICKHOFF U., 2002. Die Degradierung der Gebirgswälder Nordpakistans. Faktoren, Prozesse und Wirkungszusammenhänge in einem regionalen Mensch-Umwelt-System. Erdwissenschaftliche Forschung, 41, Stuttgart: Steiner Verlag.

SCHICKHOFF U., 2011. Dynamics of mountain ecosystems [in:] A.C. Millington, M.A. Blumler, U. Schickhoff (eds.), The SAGE handbook of biogeography. London: SAGE Publications, pp. 313-337.

SCHIMPER A.F.W., 1898. Pflanzengeographie auf physiologischer Grundlage. Jena: Gustav Fischer Verlag.

SCHMithüSEN J., 1976. Allgemeine Geosynergetik. Grundlagen der Landschaftskunde. Berlin: de Gruyter.

SCHMithüSEN J., 1985. Vor- und Frühgeschichte der Biogeographie. Biogeographica, 20. Saarbrücken: Universität des Saarlandes.

Schmitt E., Schmitt T., Glawion R., Klink H.J., 2012. Biogeographie. Braunschweig: Westermann.

SChröter C., 1908. Das Pflanzenleben der Alpen. Eine Schilderung der Hochgebirgsflora. Zürich: Verlag Albert Raustein. 
SCHWEIngRUBer F.H., 1996. Tree rings and environment. Dendroecology. Bern: Paul Haupt Verlag.

Seppë H., BennetT K.D., 2003. Quaternary pollen analysis: recent progress in palaeoecology and palaeoclimatology. Progress in Physical Geography, vol. 27, no. 4, pp. 548-579.

Simberloff D.S., Wilson E.O., 1969. Experimental zoogeography of islands: The colonization of empty islands. Ecology, vol. 50, no. 2, pp. 278-296.

Sinclair S.J., White M.D., NeWell G.R., 2010. How useful are species distribution models for managing biodiversity under future climates? Ecology and Society, vol. 15, no. 1: 8, http:// www.ecologyandsociety.org/vol15/iss $1 /$ art8/ [26 May 2014].

SpeER J.H., 2010. Fundamentals of tree-ring research. Tucson: University of Arizona Press.

SVenning J., Normand S., Kageyama M., 2008. Glacial refugia of temperate trees in Europe: Insights from species distribution modelling. Journal of Ecology, vol. 96, no. 8, pp. 1117-1127.

TANSLEY A.G., 1935. The use and abuse of vegetational concepts and terms. Ecology, vol. 16, no. 3, pp. 284-307.

TAYLOR J.A. (ed.), 1984. Biogeography. Recent advances and future directions. Lanham, MD: Rowman \& Littlefield.

Ter BraAk C.J.F., 1986. Canonical correspondence analysis: a new eigenvector technique for multivariate direct gradient analysis. Ecology, vol. 67, no. 5, pp. 1167-1179.

Thuiller W., Albert C., Araújo M.B., Berry P.M., Cabeza M., Guisan A., Hickler T., Midgley G.F., Paterson J., Schurr F.M., Sykes M.T., ZimmerMANn N.E., 2008. Predicting global change impacts on plant species' distributions: Future challenges. Perspectives in Plant Ecology, Evolution and Systematics, vol. 9, no. 3, pp. 137-152.

Thuiller W., Lavergne S., Roquet C., Boulangeat I., Lafourcade B., Araújo M.B., 2011. Consequences of climate change on the tree of life in Europe. Nature, vol. 470, no. 7335, pp. 531-534.

Tittensor D.P., Mora C., Jetz W., Lotze H.K., Ricard D., Van den Berghe E., Worm B., 2010. Global patterns and predictors of marine biodiversity across taxa. Nature, vol. 466, no. 7310, pp. 1098-1101.
TROLL C., 1939. Luftbildplan und ökologische Bodenforschung. Zeitschrift der Gesellschaft für Erdkunde zu Berlin, 7-8, pp. 241-298.

TroLl C., 1966. Landschaftsökologie als geographisch-synoptische Naturbetrachtung. Erdkundliches Wissen, 11. Wiesbaden: Franz Steiner Verlag, pp. 1-13.

Turner II B.L., LAmbin E.F., Reenberg A., 2007. The emergence of land change science for global environmental change and sustainability. PNAS, vol. 104, no. 52, pp. 20666-20671.

TWIDDLE C.L., 2012. Section 1.4: Pollen analysis: not just a qualitative tool [in:] L. Clarke (ed.), Geomorphological techniques (online edition). London: British Society for Geomorphology, http:/ www.geomorphology.org.uk/assets/publications/subsections/pdfs/OnsitePublicationSubsection/83/4.1.4_pollenanalysis.pdf

van der Maarel E., 1975. The Braun-Blanquet approach in perspective. Vegetatio, vol. 30, no. 3, pp. 213-219.

Villemant C., Barbet-Massin M., Perrard A., MulLer F., Gargominy O., Jiguet F., Rome Q., 2011. Predicting the invasion risk by the alien beehawking Yellow-legged hornet Vespa velutina nigrithorax across Europe and other continents with niche models. Biological Conservation, vol. 144, no. 9, pp. 2142-2150.

vON POSt L., 1918. Skogsträdpollen i sydsvenska torvmosselagerföljder. Forhandlinger ved de 16. Skandinaviske Naturforsheresmøte 1916, pp. 433-465.

Walter H., 1962-1968. Die Vegetation der Erde in öko-physiologischer Betrachtung. Vol. 1: Die tropischen und subtropischen Zonen. Vol. 2: Die gemäßigten und arktischen Zonen. Stuttgart: Gustav Fischer Verlag.

Walter H., BRECKLE S.W., 1983-1991. Ökologie der Erde. Vol. 1: Ökologische Grundlagen in globaler Sicht. Vol. 2: Spezielle Ökologie der Tropischen und Subtropischen Zonen. Vol. 3: Spezielle Ökologie der Gemäßigten und Arktischen Zonen Euro-Nordasiens. Vol. 4: Spezielle Ökologie der Gemäßigten und Arktischen Zonen außerhalb Euro-Nordasiens. Stuttgart: Gustav Fischer Verlag.

Warming J.E.B., 1896. Lehrbuch der ökologischen Pflanzengeographie. Berlin: Gebruder Borntraeger. 
WatTs D., 1978. The new biogeography and its niche in physical geography. Geography, vol. 63, no. 4, pp. 324-337.

Wegener A., 1915. Die Entstehung der Kontinente und Ozeane. Braunschweig: Vieweg \& Sohn.

Wen J., Ree R.H., Ickert-Bond S.M., Nie Z., Funk V., 2013. Biogeography: where do we go from here? Taxon, vol. 62, no. 5, pp. 912-927.

WhitTAKeR R.H., 1967. Gradient analysis of vegetation. Biological Reviews, vol. 42, no. 2, pp. 207-264.

WhitTAKeR R.J., 2014. Editorial: Developments in biogeography. Journal of Biogeography, vol. 41, no. 1, pp. 1-5.

WhitTAKer R.J., Triantis K.A., LAdLE R.J., 2008. A general dynamic theory of oceanic island biogeography. Journal of Biogeography, vol. 35, no. 6, pp. 977-994.
Whittaker R.J., Araújo M.B., Jepson P., Ladle R.J., Watson J.E.M., Willis K.J., 2005. Conservation biogeography: assessment and prospects. Diversity and Distributions, vol. 11, no. 1, pp. 3-23.

Wiens J.J., 2011. The niche, biogeography and species interactions. Philosophical Transactions of the Royal Society B. Biological Sciences, vol. 366, no. 1576, pp. 2336-2350.

WiLLIS J.C., 1922. Age and area: a study in geographical distribution and origin of species. Cambridge: Cambridge University Press.

Witman J.D., Roy K., 2009. Marine macroecology. Chicago: University of Chicago Press.

ZiMmerer K.S., 1994. Human geography and the 'new ecology': The prospect and promise of integration. Annals of the Association of American Geographers, vol. 84, no. 1, pp. 108-125. 